\title{
Social Structure in Naturalistic Decision Making
}

\author{
Markus Vanharanta \\ Lancaster University Management School, UK \\ m.vanharanta@lancaster.ac.uk
}

\begin{abstract}
Motivation - While much of the early NDM research emphasized technical proficiency, more recently, NDM research has begun to investigate $\operatorname{cog}$ nition in so cial contexts. As a resu lt, we argue th at NDM research can benefit from str onger theoretical linkage $s$ with social theories and the $c$ oncept of $s$ ocial structure, which has arguably been the central concept in sociological investigation. Research approach This is a th eoretical $p$ aper. Originality/Value - We build th eory of how i nstitutional, relatio nal an d embodied concepts of social structure can be used to as an analytical lens to provide rich descriptions of NDM typ e so cio-cognitive in teraction. Take away message - On tological clarity reg arding th e relationship between NDM and social structure allows NDM research to better position itself in relation to objectivist and subjectivists stereotypes and to utilize various structuration theories to address sociocognitive interaction. This contributes to our understanding of interactions between NDM typ e cognitive powers, and institutional and relational structures.
\end{abstract}

Keywords

Social structure, embodied / relational / institutional structure, socio-cognitive interaction

\section{INTRODUCTION}

Naturalistic Decision Making (NDM) related cognitive research has m ade significant contributions to ex plaining how proficient decision-makers handle dynamic and ch anging contexts and related Man-Machine systems (e.g. Klein et al. 1993; Klein 1999; Lipshitz et al. 2001; Salas and Klein 2001; Zsambok and Klein 1997). While much of the early NDM research emphasized areas of technical proficiency, more recently NDM research has begun to investigate cognition in social contexts (e.g. Gore et al. 2006; Lipshitz et al. 2006; Roth et al. 2006; Shattuck and Miller 2006). As a result, we argue that NDM related research can benefit from stronger theoretical links with social theory and the concept of social structure, which ha s arguably been $t$ he central con cept in so ciological in vestigation. In particular, we bu ild theory addressing how institutional, relational and embodied concepts of social structure can be used to as an analytical lens to provide rich descriptions of NDM type socio-cognitive interaction. This allows NDM research to better position itself in relation to objectivist an $\mathrm{d}$ sub jectivists stereo types, utilize v arious structu ration th eories to ad dress so cio-cognitive interaction, and to analytically examine dynamic interaction between institutional and relational structures and cognitive causal powers.

While this paper emphasizes the importance of social structures, at the same time, we recognize that social structure is a controversial idea eve $\mathrm{n}$ in s ocial researc $\mathrm{h}$. Interestingly, social research and cognit ive research have been bo th challenged by similar atomistic arguments, where the mind and social structure have been seen as epiphenomena. The question is if we can better ex plain the properties of the mind using lower lev el material cau sal mechanisms, and if social structures can be better explained by investigating the properties individuals. As Sawyer (2002: 233) has pointed out, this parallel between the social and cognitive research was already recognized by Durkheim in 1898:

"Each mental condition is, as regards the neural cells, in the same condition of relative independence as social phenomena are in relation to indivi dual people.... Those, then, who accuse us of leaving s ocial life in the air because we re fuse to re duce it to the individual mind ha ve not, perha ps, recognized all the consequence s of their o bjection. If it were $\mathrm{j}$ ustified it wo uld app ly $\mathrm{j}$ ust as well to the relations b etween min $\mathrm{d}$ and $\mathrm{b}$ rain" (Durkheim [1898] 1953: 28)

As another parallel, both social and cognitive research traditions have tried to counter the red uctionist argument with the idea of sy nchronic em ergence, where the collective whole is seen as more than the sum of its parts. More specifically, an "em ergent effect is not additive, not pre dictable from knowledge of its co mponents, and not decomposable into those components" (Sawyer 2001: 553).

"We all know that a system can be described as a whole or as a collection of its parts, and generally agree that with the maxim that the whole is more than the sum of its $\mathrm{p}$ arts. Yet as so on as we tu rn from the world of 
words to the world of things, we act as if the whole was merely a collection of independent parts." (Hollnagel and Woods 1999: 342)

While there are p hilosophical means to su pport the id ea of sy nchronic emerg ence, it is easier to justify the study of emergent p roperties pu rely based o $\mathrm{n}$ m ethodological gr ounds. E ven if the causal mech anisms o f the whole were already present in the cau sal mechanisms of the parts, this does not logically entail that the study of atomistic parts is the m ost appr opriate 1 evel of a nalysis ( Sawyer 2001 ). Thus, em ergent p roperties of "the $s$ ocial" can provide an appropriate analytical lens, even if it becomes later on possible to explained em ergent properties of social structures with the properties of individuals. As a parallel example, in NDM research, this type of methodological approach was used to develop the RPD-model:

"After considerable research on recognition primed decision making, we realized that the model was basically a co mbination of th ree decision heuristics th $\mathrm{at} \mathrm{h}$ ad alread $\mathrm{y} b$ een well-studied fro $\mathrm{m}$ th $\mathrm{e}$ microcognition perspective: av ailability an d represen tativeness to id entify th e typ ical co urse of actio $\mathrm{n}$, an d th e si mulation heuristic to evalu ate the co urse of actio n (Kahn eman and Tve rsky 1982). The refore, in this case it was possible to trace the macrocognitive phenomenon back to hypothetical microcognitive components. However, several decades of research on the av ailability, repres entativeness, and simulation heuristics had not led to a discovery of recognitional decision making." (Klein et al. 2003: 82)

Accordingly, there can be distinctive methodological advantages to treat social structures as if they were "real" in NDM type socio-cognitive research. To quote Sawyer (2001): "if we ca n identify that a phenomenon has causal power, then we must treat it as real."

\section{SOCIAL STRUCTURE}

As a description of social structure we adopt Lopez and Scott's (2000) theoretical framework, which tries to synthesize over 100 years of debate surrounding the concept of social structure. Lopez and Scott (ibid) describe social structure as having three $\mathrm{m}$ anifestations, nam ely institutional st ructures, rel ational st ructures an d em bodied st ructures. Fi rstly, institutional stru ctures co ncern "no rmative o $\mathrm{r}$ institu tional ph enomena: in dividuals act in ter ms o f no rmative expectations which thereby, structure their actions" (Scott 2001: 78). The importance institutional structures has been acknowledged in the definition of NDM, as "organizational norms and goals" is one of its eight defining characteristics (Orasanu and Connolly 1995: 7). Secondly, "relational structure" refers to the social relations themselves, "understood as patterns of causal interconnections and interdependence among agents and their actions, as well as the positions that they occupy." (Lopez and Scott 2000: 3). Relational structures between social agents are s een to change the atomistic properties of s ocial age nts. F or example, slave-master rel ationship, t eacher- st udent relationship, and landlord-tenant relationship all ch ange what the effected people can do. Relational structures together with institutional structures are thus part of $t$ he real life $\mathrm{c}$ ontexts of NDM type de cision-making, which s ocial age nts na vigate in everyday soci ocognitive interaction. T hirdly, the conc ept of em bodied s tructure refe rs to cognitive s tructures, whic h em body tacit social habits, norms, skills and other social predispositions (Bourdieu 1990; Giddens 1979). The concept of em bodied social structures thus provides a straight forward linkage between social theory and NDM type cognitive theory.

\section{OBJECTIVISM AND SUBJECTIVISM}

To take social structure into consideration in NDM research, social agents' co gnitive powers need to be appropriately positioned in relation to so cial stru ctures and their cau sal powers. Th is positioning needs to avo id the ex tremes of objectivist and su bjectivist stereotypes. Th e stereo type of obj ectivism po rtrays hu man beings lack ing ag ency $\mathrm{t} o$ influence their social destiny because of the powers of s ocial structures (e.g. Parker 2000). This extreme theoretical position would render individuals, and their NDM-related cognitive powers unable to influence the direction of social processes.

According to the st ereotype of s ubjectivism, individuals are seen as unconstrai ned by social struct ures (ibid). This stereotype thus describes individuals as masters of their own social destiny, effectively exaggerating the significance of cognitive causal powers in social interaction. To navigate between these extremes in an informed way, NDM research can u tilize v arious "stru cturation th eories" (e.g. Arch er 1995; Bh askar 1979; Bo urdieu 199 0; Gi ddens 197 9), which carefully reconcile the subjectivist and objectivists positions without reifying social structures. Stru cturation theories have thus tried to find a way of explaining how social structures can constrain and enable people, and their cognitive powers, while at the sa me time acknowled ging that socia 1 structures ca n only exist because of th e activity of people. Without people there are no social structures, and yet individuals cannot freely change social structures.

For NDM research, an easy en try point to structuration theory can be found in Bourdieu's and Giddens' structuration theories. This is because both Bourdieu (1977, 1990) and Giddens (1979) rely extensively on the e mbodied structure concept. Bourdieu's theory of "habitus" describes how early social experiences become an embodied as part of who we are, manifested in our social practices, for example, in the way we speak, eat, walk, and interact with others (Bourdieu 1977, 1990). Similarly, accor ding to Giddens' Structuration Theory (Giddens 1979), social structure is seen t o only 
exist in our embodied cognitive structures. Drawing an analogy between language and speech, Giddens describes the embodied social structure to have language like virt ual existence outside time-space. It is only in s ocial practices that this virtually existence of s ocial structure becomes enacted, sim ilarly to language being enacted in s peech. Naturally, institutional and relational structures dependent on embodied social structures (Lopez and Scott 2000). Yet, this does not necessarily make institutional and relational social structures less real or methodologically less significant.

As an example, Archer's $(1988,1995)$ structuration theory has significant methodological advantages. Archer bases her theorizing on critical realist philosophy of science (Archer et al. 19 98; Bhaskar 1975, 1979; Sayer 1999) where social relational and in stitutional stru ctures (or "cu lture") are seen as "real" en tities. Th is allows an an alytical sep aration between structure and agency to better investigate their interaction. By applying Archer's structuration theory to NDM research, th is separation allows u s to an alyse of the in terplay between so cial stru cture and co gnitive powers in three analytically se parate stages. At T1, social structure begins to con dition NDM, resu lting in a cognitive ad aptation to social complexity (see Figure 1). For exam ple, we were born into a particular society and social class whic h both preexisted us, and conditioned our cognitive presuppositions before we had a chance to influence back at social structures. It is only at T 2-T3 that soci o-cognitive interaction takes place, which a llows our cognitive powers to influe nce social structure (see Figure 1). In the end of the cycle, institutional, relational, and embodied structures are reproduced or elaborated as a resu lt of socio-cognitive interaction. At this point in time, these social structures have already begun to condition the next cycle of social interaction.

\section{Structural conditioning}

\section{TI}

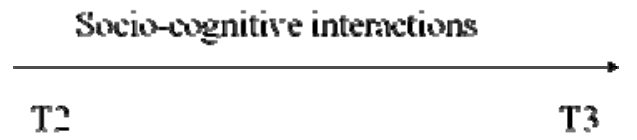

Structural elaboration

$\mathrm{T} t$

Figure1. Social NDM applied from Archer (1995: 157)

Some aspects of this three-part analytical conceptualization are already featured in NDM theory. For example, in NDM research has adopted an extended the idea of "decision making" beyond mere "decision-events".

"...decisions are em bedded in larg er task s that the decision maker is try ing to acco mplish... th at co nsist of defining what the problem is, understanding what a reasonable solution would look like, taking action to reach that goal, and evaluating the effects of that action." (Orasanu and Connolly 1995: 6)

For example, macrocognition has been described as a cog nitive adaptation to environmental complexity (e.g. Klein et al. 2003). Also, Cognitive System Engineering can be seen as an attempt to generate appropriate structural conditioning that matches co gnitive requirements. So cial NDM however $\mathrm{h}$ as an ev en broader an alytical sp an, as decision-making begins by society first sh aping the "habitus" of social agents, as a part of structural conditioning (see Figure 1.) This conditions agents to have an embodied feel for the social games being played in a part icular social "field" (Bourdie u 1977, 1990). This influences how social agents define problems, evaluate reasonable solutions, take action, and evaluate the effects of that action. In addition, NDM type decision-making has structural consequences as NDM reproduces and elaborates social structures (T3-T4), including our embodied presuppositions and related skills. Analytically speaking, social NDM $t$ hus begins before ag ents begin to ev aluate the $n$ ature of $p$ roblems, an d continues after so cio-cognitive interaction is finished (see Figure 1). This means that social NDM exte nds the analytically relevant domain NDM in both temporal directions.

\section{IMPLICATIONS}

Our proposed social-turn in NDM research proposes to use social structures as a methodologically lens to provide richer descriptions of NDM in real life soci al contexts. If this argum ent is a ccepted the n NDM-related research needs to 
carefully p osition itself $\mathrm{i} n$ relatio $\mathrm{n}$ to objectivist an d subjectivist stereo types. Accordingly, en tirely su bjectivist (or objectivist) socio-cognitive ex planations can not be seen as satisfactory th eoretical exp lanations of social NDM. Thi s has si gnificant i mplications to ex ample Co gnitive System En gineering in so cial con texts, as we cann ot assu me th at relational, institutional and e mbodied structures follow ideal system designs. Instea d, ela boration of socio-c ognitive systems can be desc ribed using structuration the ories, which care fully theorize agents' bounded powers to influence social systems. Accordingly, social ordering is lik ely to be a co ntinuous activity striving to maintain / achieve social order. Recognizing the nature of soci al structures thus provides an a dditional clarification re garding the real $\mathrm{m}$ of $\mathrm{t}$ he possible. Thi s is largely a matter of ackno wledging the una voidable prese nce of unintended co nsequences ( Weber 1947), contradictions, and other unavoidable tensions within social systems.

"Society is t hat wh ich nob ody wants, in the fo rm in wh ich they encounter it, for it is an unintended consequence. Its co nstitution could be expressed as a ri ddle: what is it th at depends on human in tentionality but never conforms to their intentions? What is it that relies upon people's concepts but which they never fully know? What is it that depends upon action but never corresponds to the actions of even the most powerful? What is it th at has no form without us, yet which forms us as we seek its transformation. And what is it that never satisfies the precise design of anyone yet because of this always motivates its attempted reconstitution?" (Archer 1995: 165)

In addition, value-rationality (or phronesis) has received relatively little attention in NDM research, which the inclusion of the social dimension problematizes. As a resu lt it becomes increasingly difficult to use purely cognitive arguments to determ ine how a soci o-cognitive syst em should look like. At the sam e tim e, NDM resea rch can cont ribute to theoretical explanations of how social agents make value-rational judgments in real-life social contexts, and how this results in the reproduction / elaboration of social structures. This objective can be facilitated by expanding the analytical domain relev ant to NDM, as we h ave propo sed i n Fig ure 1. Val ue-rationality is in deed $\mathrm{p}$ art o f to NDM as "organizational norms and goals" are included in the definition of NDM (Orasanu and Connolly 1995: 7).

Thirdly, we argue that it is signi ficant to find a better theoretical accommodation between NDM type decision-making and organizational bureaucracies. In particular, it is im portant to recognize that while bureaucracies have various well documented shortcomings, NDM type decision-making cannot entirely eliminate bureaucratic forms of social ordering. In a ddition, despite its shortcomings it is not always desirable to re place bu reaucratic rigidities with NDM ty pe decision-making. For example, in "In Praise of Bureaucracy" Paul du Gay (2000) describes bureaucracy as having the benefit of en couraging s ystemic fairn ess. In so me situ ations, we can indeed i mprove sy stemic fai rness $t$ hrough bureaucratic means. Naturally, the reverse can as well be tr ue. There are numerous examples of organizational failure because of both too rela xed, or too stri ngent burea ucratic controls. As a result, we need to bette $r$ unde rstand the interaction bet ween burea ucracies and N DM t ype deci sion-making, a s soci al o rdering often de pends on a del icate balance and interaction between these two seemingly contradictory positions. This question can be partly addressed by examining th e an alytically distinctive stag es of stru ctural con ditioning, so cio-cognitive in teraction, an $\mathrm{d}$ st ructural elaboration (see Figure 1.)

Lastly, we argue that the social-turn in NDM requires a new kind of vocabulary and linguistic sensitivity that takes into consideration the various dualisms, in determinacies, unintended consequences, value rationalities, politics, and power considerations of socio-cognitive interaction. In particular, it is important to avoid language that inadvertently describes the social context as a "hydraulic system", designed and controlled by powerful puppet masters.

\section{REFERENCES}

Archer, M., et al. (1998), Critical Realism: Essential Readings (London: Routledge).

Archer, M. (1988), Culture and Agency (Cambridge: Cambridge University Press).

Archer, M. (1995), Realist Social Theory: The Morphogenetic Approach (Cambridge: Press Syndicate of the University of Cambridge).

Bhaskar, Roy (1975), A realist theory of science (Leeds: Leeds Books).

Bhaskar, Roy (1979), The Possibility of Naturalism (Hassocks: Harvester).

Bourdieu, Pierre (1977), Outline of a Theory of Practice (London: Cambridge University Press).

Bourdieu, Pierre (1990), The Logic of Practice (Cambridge: Polity Press).

Du Gay, P. (2000), In Praise of Bureaucracy: Weber, Organization and Ethics (London: Sage).

Durkheim, E. ([ 1898] 1953), 'Individual and Collective Representation', Sociology and Philosophy (Glencoe, IL: Free Press), 1-34.

Giddens, A. (1979), Central Problems is Social Theory (London: Macmillan). 
Gore, Julie, et al. (2006), ' Naturalistic Decision Maki ng and Or ganizations: R eviewing Pr agmatic Science', Organisation Studies, Vol. 27, No. 7, pp. 925-42.

Hollnagel, Erik and Woods, David (1999), 'Cognitive System Engineering: New Wine in New Bottles', Int. J. HumanComputer Studies, Vol. 51, pp. 339-56.

Kahneman, Daniel and Tversky, Amos (1982), 'The Simulation Heuristic', in Daniel Kahneman, Paul Slovic, and Amos Tversky (e ds.), Judgment Under Uncertainty: Heuristics and Biases (Ca mbridge: C ambridge Un iversity Press), 201-08.

Klein, Gary (1999), Sources of power: How people make decisions (Cambridge, Massachusetts: The MIT Press).

Klein, Gary, et al. (2003), 'Macrocognition', IEEE Intelligent Systems, Vol., No. May/June, pp. 81-85.

Klein, Gary, et al. (eds.) (1993), Decision Making in Action: Models and Method (1995 edn., Norwood, New Jersey: Ablex Publishing Corporation ).

Lipshitz, Raanan , K lein, G ary, an d Orasanu, Ju dith (2001), 'Fo cus Article: Tak ing Sto ck of Natu ralistic D ecision Making', Journal of Behavioral Decision Making, Vol. 14, pp. 331-52.

Lipshitz, Raanan, Klein, Gary, an d Car roll, Joh n S. (2006), 'I ntroduction to the Sp ecial I ssue. N aturalistic D ecision making and Organizational Decision Making: Exploring the Intersections', Organization Studies, Vol. 27, No. 7, pp. 917-23.

Lopez, Jose and Scott, John (2000), Social Structure (Buckingham: Open University Press).

Orasanu, J udith an d C onnolly, Terry ( 1995), ' The R einvention of Decision M aking', in Gary Kl ein, et al . (e ds.), Decision Making In Action: Models and Methods (New Jersey: Ablex Publishing Corporation).

Parker, John (2000), Structuration (Buckingham: Open University Press).

Roth, Emilie, Multer, J ordan, an d R aslear, Th omas (20 06), ' Shared Si tuation A wareness as a C ontributor to Hi gh Reliability Performance in Railroad Operations', Organization Studies, Vol. 27, No. 7, pp. 967-87.

Salas, Eduardo and Klein, Garry (eds.) (2001), Linking Expertise and Naturalistic Decision Making (London: Lawrence Erlbaum Associates, Publishers).

Sawyer, R. K eith (2001), 'Emergence in Sociology: C ontemporary P hilosophy of M ind and Some Implications for Sociology Theory', American Journal of Sociology, Vol. 107, No. 3, pp. 551-85.

Sawyer, R. K eith (2002), 'D urkheim's Dilemma: Towards a So ciology of Emergence', Sociological Theory, Vol. 20, No. 2, pp. 20.

Sayer, Andrew (1999), Realism and Social Science (London: Sage).

Scott, J ohn (2001), 'Where is So cial St ructure?', in J ose Lo pez a nd Garry Potter (eds.), After Postmodernism: An Introduction to Critical Realism (London: The Athlone Press), 77-85.

Shattuck, Lawren ce G. and Miller, Nita Lewis $(20$ 06), 'Extending Nat uralistic Decision Makin g to C omplex Organizations: A Dynamic Model of Situated Cognition', Organization Studies, Vol. 27, No. 7, pp. 989-1009.

Weber, M . (1947), The Theory of Social and Economic Organization, ed . Talco tt Parso ns (New York : Oxford University Press).

Zsambok, Caroline E. and Klein, Gary (eds.) (1997), Naturalistic Decision Making (New Jersey: Lawre nce Erlbaum Associates). 